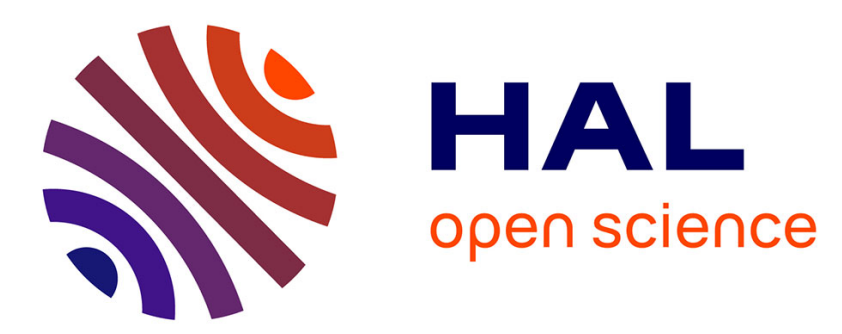

\title{
Genealogy of mining territories in the Atacama Desert: The production of modern waterscapes in Tarapacá region, northern Chile (1853-1924)
}

Manuel Mendez

\section{- To cite this version:}

Manuel Mendez. Genealogy of mining territories in the Atacama Desert: The production of modern waterscapes in Tarapacá region, northern Chile (1853-1924). The Extractive Industries and Society, 2021, 8 (1), pp.111-122. 10.1016/j.exis.2020.05.003 . hal-02932299

\section{HAL Id: hal-02932299 \\ https://hal.science/hal-02932299}

Submitted on 17 Sep 2020

HAL is a multi-disciplinary open access archive for the deposit and dissemination of scientific research documents, whether they are published or not. The documents may come from teaching and research institutions in France or abroad, or from public or private research centers.
L'archive ouverte pluridisciplinaire HAL, est destinée au dépôt et à la diffusion de documents scientifiques de niveau recherche, publiés ou non, émanant des établissements d'enseignement et de recherche français ou étrangers, des laboratoires publics ou privés. 
GENEALOGY OF MINING TERRITORIES IN THE ATACAMA DESERT: THE PRODUCTION OF MODERN WATERSCAPES IN TARAPACÁ REGION, NORTHERN CHILE (1853-1925)

\author{
Manuel Mendez ${ }^{\text {a }}$ \\ Rennes Cedex, France. \\ 380, 1410000 San Pedro de Atacama, Chile. \\ E-mail address: manuel.mendez@,univ-rennes2.fr \\ ORCID iD: https://orcid.org/0000-0002-7276-0514
}

${ }^{a}$ Laboratoire CReAAH-LAHM, Université de Rennes 2, Av. du Général Leclerc-CS 74205, 35042

b Instituto de Arqueología y Antropología (IAA), Universidad Católica del Norte, Gustavo Le Paige

\begin{abstract}
$\underline{\text { ABSTRACT }}$
From a political ecology perspective, Chilean geographers have studied the various aspects of socioenvironmental conflicts over water during the neoliberal period starting in 1973. This study aims to contribute to the understanding of the relationship between the different meanings and materialities of water in the Tarapacá region of northern Chile prior to the introduction of neoliberal reforms using a geohistorical perspective. By reviewing historical archives and undertaking terrain analyses, we examine the respective roles of the state, capitalism, and science/technology in the commodification/modernization of water in Tarapacá from the $19^{\text {th }}$ to the early $20^{\text {th }}$ centuries. We propose that the $19^{\text {th }}$-century insertion of Tarapacá's nitrate mining into the world capitalist circuit of minerals attracted explorers and scientists, who proffered modern discourses on nature and water while denying any local knowledge about water. These discourses then became prominent in the political sphere and were hegemonized through laws and norms. In parallel, the modernization of the nitrate mining resulted in the introduction of cutting-edge technologies for water infrastructure, a process that introduced changes in everyday practices regarding water, leading to the creation of the modern waterscapes in Tarapacá.
\end{abstract}

\title{
$\underline{\text { KEYWORDS }}$
}

Genealogy, Mining territories, Waterscapes, Modernization, Atacama Desert

\section{INTRODUCTION}

Over the past 30 years, growing concerns have emerged in the Chilean society and among the social scientists interested in conflicts over access to and ownership of water, being reflected by the increasing number of publications and meetings, as well as the creation of several citizens' associations. Similarly, since October 2019, the Chilean social movement has targeted conflicts over water as the most urgent socio-environmental problem in the country. In this context, Chilean geography has been attending to this topic since the early 1990s. Bauer (1995) was the first scholar to analyze water struggles in the context of the new water legislation imposed by Augusto Pinochet in 1981. Since his seminal work, other perspectives have appeared in the critical analysis of water (e.g., Budds, 2004, 2009; Yáñez and Molina, 2008, 2011; Molina, 2012; Romero et al., 2012; Prieto, 
2015, 2019). Nevertheless, most of these studies have sought to understand the effects of the neoliberalization of nature and water since 1980, overlooking the historical transformation of the northern Chilean territories into a globally significant mining region, where conflicts over water have become more visible and recurrent since the beginning of the $20^{\text {th }}$ century.

From an Andean perspective, water struggles in the context of mining territories in the Andes have been extensively studied (e.g., Perreault, 2006, 2014; Bebbington and Williams, 2008; Boelens et al., 2011; Budds and Hinojosa, 2012; Arroyo and Boelens, 2013). Although these studies advance a critical understanding of the conflictive scenarios around water, they have largely overlooked certain longstanding discursive and material processes that set the conditions for the production of modern water and the associated conflicts (Linton, 2010). Furthermore, long-term perspectives have been developed in other territories to understand the modernization of water, for example, the westem territories of the United States (Worster, 1985), the island of Bali (Lansing, 1991), Greece (Kaika, 2006), or Spain (Swyngedouw, 1999, 2015). In this sense, we highlight three research exceptions focusing on the Meridional Andes: the modernization process of the Rímac river in Lima (Hommes and Boelens, 2018), the insertion of mining activity and water extraction from indigenous communities in the Antofagasta region (Carrasco, 2015), and the study of the intertwined production of miningscapes and waterscapes during the nitrate period in the Taltal district (Méndez et al., 2020).

Following the "territorial genealogy" (Peluso and Vandergeest, 2001; Elden, 2010) and "waterscape" (Swyngedouw 1999, 2015) perspectives, this study seeks to problematize the production of new conceptions and materialities of water, which appear entangled with the introduction of the capitalist mining of nitrate in the Tarapacá region. Tarapacá is situated between $19^{\circ}$ and $21^{\circ} 30^{\prime} \mathrm{S}$ in northern Chile (Figure 1). After being administered by the Viceroyalty of Peru (1542-1821) and the nascent Peruvian state (from 1821), Tarapacá became a Chilean region during the Pacific War. ${ }^{1}$ Although the nitrates of Tarapacá, ${ }^{2}$ concentrated in the Pampa del Tamarugal zone (PdT), were exploited prior to the colonial era, in the $1810 \mathrm{~s}$, exploitation by industrial mining started. Nitrate mining helped transform the region into a territory of geostrategic interest to the nascent states of Peru and Chile. Over time, the nitrate industry became the main economic activity of the country, until the crisis of the 1920s. Nowadays, the Tarapacá region continues to be one of the main mining regions in Chile. At the same time, Tarapacá faced strong struggles over water between this activity and different segments of the regional society.

\footnotetext{
${ }^{1}$ The Pacific War (1879-1883) was a conflict involving the armed forces of Bolivia, Peru, and Chile. After the war, which was rooted in disputes over the ownership and exploitation of nitrates, the Provincia Litoral of Bolivia (currently, the Antofagasta region) and the Peruvian regions of Tarapacá and Arica (currently, the regions of Tarapacá and AricaParinacota, respectively) came to be administered by Chile.

${ }^{2}$ Nitrates are a combination of salts and minerals, being used in Europe and the United States as fertilizers during the agricultural boom of the late $19^{\text {th }}$ and early $20^{\text {th }}$ centuries (Fernández, 1981).
} 
Figure 1: Tarapacá region and Pampa del Tamarugal zone

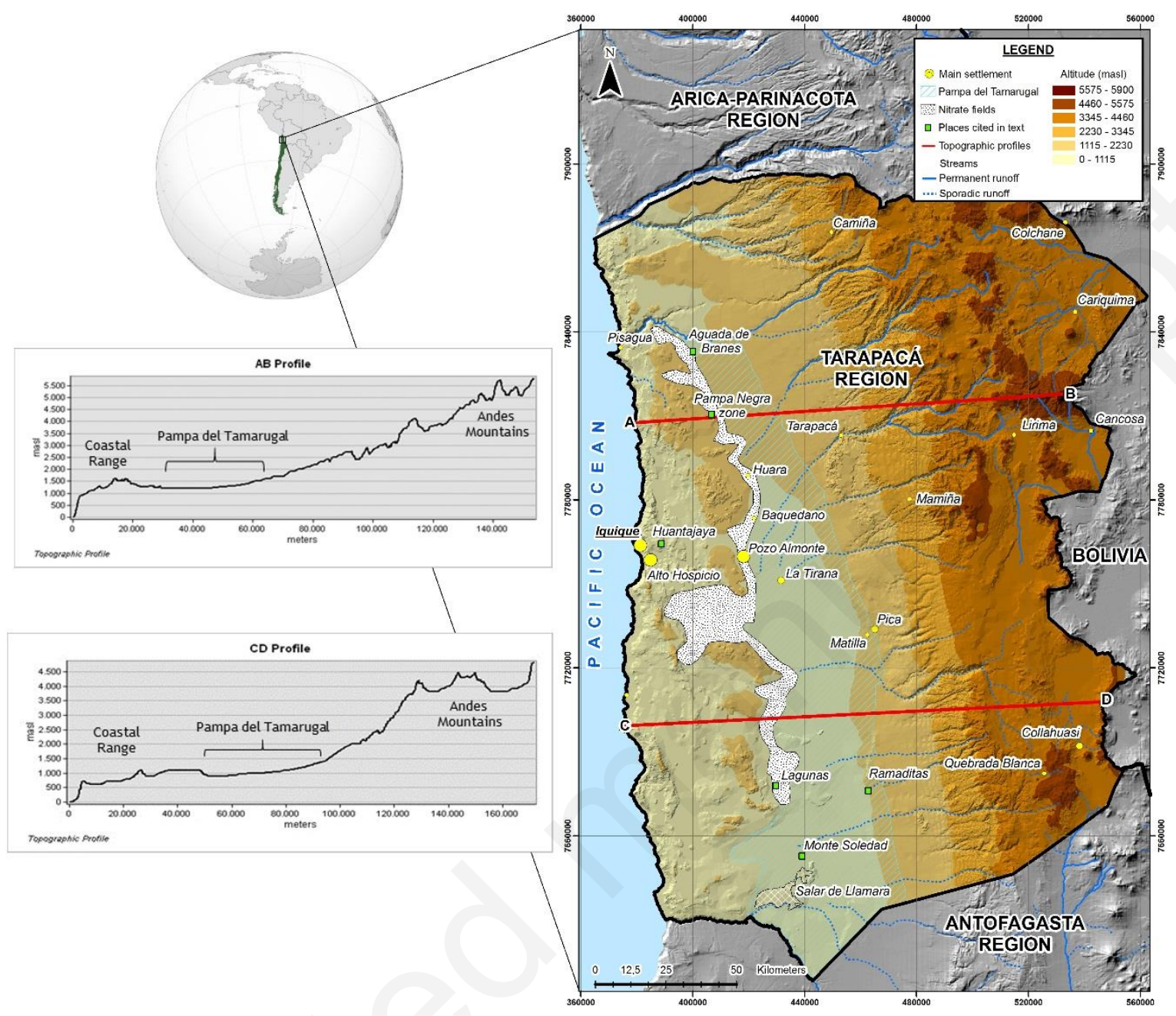

Source: Elaborated by the authors.

This paper proposes that the introduction of the Tarapacá mining region into the global circuit of commodities and the emergence of the states of Peru and Chile in the $19^{\text {th }}$ century stimulated the modernization of these territories. During this socionatural process, two principal mechanisms altered the waterscapes in Tarapacá. On one hand, a hegemonic discursive process simplifies "naturalizing" water, which becomes an economic resource. On the other hand, entwined with the discursive process, a material transformation of everyday practices regarding water in the Pampa del Tamarugal zone removes this element from social contact. Through the installation of an interconnected web of pumps and pipes, water was ghostly extracted and conducted towards its most efficient use: nitrate mining. This modernization process produced uneven waterscapes and transformed the waters of the "driest desert in the world" into a scarce resource for people but abundant for mining.

Moreover, considering the mining boom that the Meridional Andes have experienced since the 1990s (Romero et al., 2012; Bury and Bebbington, 2013; Svampa, 2019), we propose that the geohistorical understanding of production in Tarapacá region as a mining territory and how this process transformed the conceptions and uses of water invite a regional discussion on the relationship between territory, water, mining, and social struggles in the Meridional Andes as a main mining zone worldwide (United States Geological Service, 2019). 
2. TERRITORIAL GENEALOGIES, WATERSCAPES, AND MODERNIZATION AS CRITICAL APPROACHES IN THE STUDY OF WATER

Following Foucault (1975), a genealogical perspective implies the analysis of the things, facts, and ideas that make possible a particular phenomenon or process. Therefore, an examination of the genealogy of mining territories would entail the study of the discursive and geohistorical conditions that produced these phenomena (Peluso and Vandergeest, 2001). Additionally, Elden (2010) has proposed that the genealogy of territories necessarily involves the reconstruction of the history of ideas and concepts with respect to the production of those territories, without neglecting the analysis of everyday practices and power relations configured around these imaginaries.

Concerning everyday practices regarding water, Ekers and Loftus (2008) argue that, according to a Foucauldian perspective, these actions can be understood as a dispersed form of power that becomes connected as industrial capitalism advances. Such accumulated forms of power may, in turn, be interpreted as the everyday materialization of the production of a broader hegemonic project as a Gramscian appreciation of the integral state. Following these ideas, everyday practices concerning water (here, the actions associated with the mechanization of water) may account for the hegemonic production of some groups over others. In the case of nitrate mining in Tarapacá, this is represented by the capital and state over local communities.

Pursuing a dialectical and relational approach, nature and society do not exist separately or before the processes, flows, and relationships that constitute them constantly and indissolubly (Latour, 1991; Harvey, 1996; Smith, 2008). By applying this perspective to the study of water, Swyngedouw (1999) argues that the water-society relationship should be addressed through a "waterscapes" perspective. According to Karpouzoglou and Vij (2017), the waterscapes approach enables a more complex understanding of the installation of hegemonic positions with respect to the conceptualization, control, and use of water. Therefore, in this paper a waterscape will be understood as a socionatural entity, constituted by power relations and represented by the flows, materialities, and social practices, as well as by imaginaries, discourses, and systems of knowledge (Swyngedouw, 1996, 1999; Budds and Hinojosa, 2012). In this sense, the study of waterscapes not only challenges the modern paradigm of science, but also contests and overcomes the technocentric analyses of water that ignore key elements such as power relations or the historical perspective of the hybrid.

Conversely, Scott (1998) claims that the process of modernization is a complex mechanism of reality simplification, with the aim of achieving greater control over nature and society. For Scott (1998), the beginning of this process is associated with the establishment of the modern states that sought to make land tenure and nature "legible" (by measuring, codifying, and simplifying) for tax and administrative purposes. Measurement was mainly undertaken through cadasters and cartography, while codification was discursively materialized through the imposition of an occidental scientific understanding and operationalized through legislation. Similarly, Swyngedouw (2015) proposes that modernization is a social, political, and economic process that seeks to produce new "natures" (materially and symbolically) as well as new power relations to access these new geographies. Therefore, this modernization processes involves the simplification of the entire nature via economic production. In this way, nature elements become "natural resources" (Scott, 1998, p. 39).

Concerning the meaning of "modern water," Worster (1985), Lansing (1991), Scott (1998), Linton (2010), Swyngedouw (2015), and others propose that this conception was created between the $17^{\text {th }}$ and the beginning of the $20^{\text {th }}$ centuries, depending on the region. With modernity, water became objectified, was materially produced by technology, and was discursively constructed at the same time by political and scientific actors. Further, Braun (2000) proposes that, although there are different social productions of knowledge about nature (here, water), such as state, science, or society, 
such knowledge is not equally valid, hence the official discourses on nature (here, the hegemonic discourses on water) are key to understanding its material transformation towards circuits of capital.

\section{THE NITRATE MINING BOOM AND THE INSERTION OF TARAPACÁ INTO THE GLOBAL CIRCUIT OF MINERALS}

Mining is present in the Atacama Desert since at least 12,000 years before present (BP) (Salazar et al., 2011), constituting a central activity of the pre-Hispanic societies that inhabited the central and southern Andes (Núñez, 1987). In the Tarapacá region, the first mining records were associated with copper smelting in the settlement of Ramaditas (PdT), fragments being dated to 2,000 years BP (Graffam et al., 1996).

The first traces of the exploitation and use of nitrates in Tarapacá were associated with pre-Hispanic agriculture (Hernández, 1930). From the late $17^{\text {th }}$ century, nitrates were exploited to produce "black powder," used in silver mining operations (Bermúdez, 1963). Despite these historic uses, the production of this element came to attain economic significance towards the end of the colonial period, with the introduction of Tadeo Haenke's refining method in 1810 (a physical-chemical process to obtain potassium nitrate from sodium nitrate). Via such technical means, between 1811 and 1812, the first modern nitrate mines were established. Locally called oficina de paradas, this refining method was used until the end of the $19^{\text {th }}$ century.

Since the installation of oficinas de paradas and until the end of the $1830 \mathrm{~s}$, the production of nitrate remained oriented towards the production of powder. In parallel, biochemical studies were being conducted in Europe and the United States to understand the importance of nitrogen compounds for vegetable farming. Their results stimulated the use of nitrates in the impoverished soils of the Northern Hemisphere. In this context, the introduction of Tarapacá's nitrates as fertilizers in European and North American markets in the 1840s boosted their production (Bermúdez, 1963; Fernández, 1981).

From 1853, the introduction of steam by the Gamboni method and the mechanization of production led to the industrialization of nitrates. However, high production (all supplies had to be brought from long distances) and transportation costs between oficinas and the ports of Tarapacá delayed the production peak for a couple of decades.

The decline of the guano economy in Peru (which helped stimulate the state's interest in Tarapacá) in the 1860s, construction of the first railroad (1871), introduction of the Shanks refining method (1878), and arrival of large amounts of English capital following the Pacific War provided a definitive impulse to the nitrate industry. Indeed, by 1878 , there were more than 160 nitrate mines. After the Pacific War, between 1883 and 1919, Chile exported more than 50 million metric tons, valued in 1919 at GBP 402 million (Nyre, 2020). ${ }^{3}$ Moreover, by 1917, regional production reached a peak of more than 3 million tons (Hernández, 1930; Bermúdez, 1963; Cariola and Sunkel, 1982; Thompson, 2005; González, 2014).

Following successive crises, the nitrate mining boom ended abruptly after World War I. Scholars have identified the following key causes of its collapse: technological backwardness, inadequate economic administration of the mines, decrease in ore grade, high transportation costs between Tarapacá and the consumption centers in Europe and United States, and most crucially the arrival of

\footnotetext{
${ }^{3}$ Following Nyre (2020), this figure equals above USD 24 billion in current prices (USD 24,748,853,558.12).
} 
synthetic nitrogenous compounds to the fertilizer market (Hernández, 1930; Fernández, 1981; González, 2011, 2014).

Despite the region's significant mining history, it was the industrialization of nitrate mining that introduced the main discursive and material changes that helped transform Tarapacá into a mining territory that operated in the global circuit of commodities. Consequently, various scientific, state, and private discourses (analyzed in Section 4) played a central role in the material transformation of nature (water and nitrates) into commodities. From a material perspective, over 90 nitrate mines operated in Tarapacá in the studied period and helped reconfigure the infrastructure of the region (e.g., road system, settlements, railways, water supply, ports). The modern mining configuration implied the production of both peripheral (extraction and socio-environmental impacts) and central $\operatorname{areas}^{4}$ (exports and accumulation).

\section{DISCOURSES OF WATER IN TARAPACÁ: FROM SCARCITY TO SCIENTIFIC ABUNDANCE AND THE PRODUCTION OF "BAD" WATER}

From the first incursion of the Spanish conquistadors in the mid- $16^{\text {th }}$ century, the Atacama macroregion was described as an uninhabited space with extreme water scarcity. One of the first written descriptions of Tarapacá region was by Jerónimo De Vivar, published in 1558. Vivar was a Spanish geographer from the expedition led by the first Governor of Chile, Pedro de Valdivia. Vivar wrote: "All the compass of land that is outside the valleys is barren and unpopulated and of large sands. In all this land compass between these valleys it does not rain" (1558, ch. 5, p. 9).

Concerning mining and water, different reports highlight the relationship the Spanish Crown quickly established in Tarapacá. For instance, Pedro Pizarro indicated: "Here in Tarapacá there are great and riche mines, which are unworked for lack of water and firewood" (1571, ch. 26, p. 63). In 1765, Antonio O'Brien undertook a study of Huantajaya mine, concluding that its low profitability was explained by its lack of water (Donoso, 2008). O'Brien (1765) subsequently proposed a hydraulic project to drive different sources of water from the Andes Mountains to the mining areas. Although this plan was not materialized for political and economic reasons, it was the first mining project to (discursively) transform water into a "legible" element according to Scott's (1998) use of the term.

Since Peru's independence in 1821 and until the 1870s, the presence of the Peruvian state apparatus in Tarapacá was weak, being limited to customs activities as well as the exploration of new sources of wealth, especially mining and water. In this sense, Hernández (1930) has indicated that in the first decades of the Peruvian administration, the state presence in Iquique was limited to a "small hovel," which functioned as the customs office (Hernández, 1930, p. 28). Therefore, the first territorial analyses commissioned by the modern state were mandated in 1827 by the first Intendant of Tarapacá, Ramon Castilla (who later became the president of Peru). Thereafter, several expeditions were made in the region for state, scientific, or private purposes (Table 1).

\footnotetext{
${ }^{4}$ Although the towns of Iquique and Pisagua were transformed into "central areas" at the local level, the configuration of the capital owners of the nitrate mines involved that the wealth generated by the nitrate mining of Tarapacá was concentrated at the national (Santiago-Valparaíso) and international levels (England) (González, 2011).
} 
Table 1: Main studies carried out in Tarapacá, 1827-1936.

\begin{tabular}{|c|c|c|c|}
\hline Scholars & Year of study (visit) & Sponsor & Central element of research \\
\hline $\begin{array}{c}\text { W. Bollaert and } \\
\text { G. Smith }\end{array}$ & $1827-1860$ & Peruvian state & Geography \\
\hline C. Darwin & $(1835)$ & Great Britain & Geology \\
\hline J. Blake & 1843 & Private & Mining \\
\hline F. Puelma & 1855 & University of Chile & Geology and mining \\
\hline M. de la Fuente & 1856 & Private & Geography and mining \\
\hline A. Raimondi & $1853,1882,1884$ & Peruvian State & Nitrate mining and water \\
\hline D. Forbes & 1860 & Private & Geology \\
\hline M.S. Church & $(1861)$ & Peruvian state & Water \\
\hline F. Torrico & 1871 & Peruvian state & Water \\
\hline G. Fitzroy Cole & 1874 & Town Hall of Iquique & Water \\
\hline M. Paz Soldan & 1877 & Peruvian state & Geography \\
\hline A. Bertrand & 1880 & Chilean state & Geography, water, and \\
nitrate mining
\end{tabular}

We highlight the detailed descriptions of the different geological formations in the region, along with their chemical compositions, as well as the identification of potential sites for mining (Blake, 1843; Forbes, 1860; Darwin, 1878). Moreover, the discourse on the inefficiency of the paradas system was repeated in the description of the nitrate industry (Blake, 1843; Forbes, 1860; Puelma, 1855).

Related to water studies and in contrast to the colonial discourse that emphasized the absolute absence of water, in the second half of the $19^{\text {th }}$ century, the scientists indicated that PdT was a territory with "plenty" of water. Specifically, the only way that this "resource" could be rendered accessible was through science (hydrogeological studies) and technology (water pumps and pipeline systems) (Church, 1863; Billinghurst, 1893; Bruggen, 1921, 1936).

Another remarkable element within Tarapacá's water studies was the high number of investigations regarding the groundwater of the PdT (among the 11 water studies, only three analyzed the totality of the waters sources present in the region). Further, the PdT waters were repeatedly described as "bad waters," as most studies classified water according to taste, content of physical-chemical elements, and, by the end of the $19^{\text {th }}$ century, quantity (volume).

In 1835, as part of the H.M.S. Beagle expedition, Charles Darwin visited Tarapacá. In his notes on the journey to the nitrate mines, he described the landscape of the region and the characteristics of the nitrate industry. Concerning water, he wrote: "The country is here as unproductive as near the coast; but water, having rather a bitter and brackish taste, can be procured by digging wells" (1878, p. 364). The first description of the waters of Tarapacá as a physical-chemical compound was made by Blake (1843). Although he did not present a chemical analysis or a classification, he indicated that "the water contains a small portion of carbonate of soda," explaining its bad taste (1843, p. 5). 
Following the same logic, the different waters of PdT have been described as follows (phrases highlighted by the author):

After a long journey, "[we] were devoured by a fiery thirst, we were brought water, we drank with greed, but I immediately felt the throat on fire, because this water was salty and very brackish. I made such a grimace and I uttered such a resounding gulp that everyone laughed" (D’Ayzac, 1855, p. 205).

"The waters of Chintagüay and Pica are thermal, their heat is $20^{\circ}$ to $30^{\circ}$ centigrade, and, although not free of a taste of lime and earth, are potable and serve for agriculture." (Church, 1863, p. 62)

Regarding the waters of the nitrate mine of Lagunas, "this water is so saturated with salts that it becomes useless even for the purification of nitrate, because it can dissolve only a small amount" (Raimondi, 1882, p. 234).

The most complete and modern studies on the waters of Tarapacá were made by Church (1863), Raimondi (1882, 1884), Billinghurst $(1887,1893)$, and Bruggen $(1921,1936)$. Each of these scholars travelled across the region to analyze its characteristics and propose a classification of zones according to the waters' chemical content, depth at which they were found and possible origins, and volumes. All proposed that the quantity of mineral salts and other organisms present in the water were the most important characteristics in determining their utility for social and economic activities.

Additionally, another characteristic of these works is the "naturalization" of nature, that is, the absolute separation and independence of the physical characteristics of nature from society. However, they discuss little or nothing about sociocultural characteristics, with the exception of Bollaert (1851, 1860). Furthermore, no mention is made of the relationships between local communities and water (see Section 5). All this complexity was carefully erased from the official history and geographical descriptions of Tarapacá, being replaced by a unique vision of water as a resource and an element of the nitrate mining circuit and a physical-chemical compound of elements.

\section{MATERIALITIES AND EVERYDAY PRACTICES AROUND WATER IN PDT}

The contemporary historical, anthropological, archaeological, and geographical studies indicate that the communities that inhabited and/or moved through Tarapacá possessed a complex conception of nature. Moreover, for these local societies, water was a central element of their worldview, as well as their beliefs and economic and social activities (Núñez, 1985; VanKessel, 1985, 2003; Álvarez, 2014; Santoro et al., 2017). In this context, despite the fact that the colonial period introduced important changes into the territorial production in Tarapacá (Méndez and Romero, 2018, 2020), water continued to be the structuring axis of the territories in the region (Martínez, 1987; Valencia, 2002; Castro, 2004).

During the first decades of the nitrate period, the travel notes of Bollaert $(1851,1860)$, Raimondi $(1852-53)^{5}$, and Church (1863) highlighted the springs ${ }^{6}$ as the central nodes of PdT. Nevertheless, with the industrialization of nitrate mining, everyday practices regarding water were heavily changed

\footnotetext{
${ }^{5}$ The notes that Raimondi made in his 1852-53' travel were published by Castro et al., (2016)

${ }^{6}$ We define "springs" as the wells constructed in PdT at different historical times. These aguadas or norias (local names) supplied water for travelers and/or for economic activities. In PdT, there are only three "natural" springs: Aguada de Branes, Lagunas, and Salar de Llamara.
} 
by the introduction of cutting-edge technologies of water extraction and conduction linked to the different refining methods of nitrate: Haenke (from 1810), Gamboni (since the introduction of steam in 1853), and Shanks (from 1878).

Indeed, we propose that eachrefining method was associated with a specific form of water extraction, use, and understanding. In this sense, we summarize the PdT's everyday practices around water under three different "configurations,": springs, donkeys, and pumps. The setup of each everyday practice around water configurations did not imply the total removal of others. However, the pump configuration was intertwined with the Shank method, a mechanism adopted by most mines in operation since the 1880 s.

\section{$\underline{\text { Spring configuration }}$}

In PdT, over the past 3,000 years BP, permanent and sporadic settlements as well as historical trails followed the presence of water (Santoro et al., 2017). In pre-Hispanic times, the main uses of these spaces were resting places for caravans, economic interchange, ceremonies, and sporadic agricultural plots (Barnard and Dooley, 2017). Consequently, we propose that, over this period, spring areas were complex socio-environmental territories that emerged from the co-production of climatic, hydrologic, geologic, social, cultural, economic, cosmological, and other elements.

With the boom of Huantajaya silver ore in the $18^{\text {th }}$ century (Donoso, 2008), the principal springs of the PdT (located around the current settlement of La Tirana) were used for the processing of the mineral, owing to the availability of water and firewood (Billinghurst, 1893). From this moment onward, although the springs continued to function as complex territories, the utilitarian use of water for mining became essential in the everyday practices of these places.

During the first period of the modern production of nitrate (1810-1853), springs were used as resting places for the caravans that supplied the nitrate mines, as camping places for the lumberjacks, ${ }^{7}$ and for the installation of small chacras sin riego ${ }^{8}$ (Blake, 1843; Bollaert, 1851). Even when most of these spaces were abandoned due to the reduction of caravan numbers after the arrival of the railway in the 1870 s, they still existed in the $20^{\text {th }}$ century (Bowman, 1924).

In the context of nitrate mining, the construction of wells associated to Haenke's method was considerable. This refining process was only compatible with high-grade ores and constant efforts were made to search for new sites to exploit, with a new water well being constructed in each productive camp (Bermúdez, 1963). In material terms, the wells were installed next to the production zones and water extraction was mainly undertaken by hand, using ropes and containers with human and animal traction (Figure 2).

\footnotetext{
${ }^{7}$ The name Pampa del Tamarugal comes from the Prosopis tamarugo arboreal specie that, along with others (e.g., Shinus molle, Prosopis alba, Geoffroea decorticans), populated this part of the Tarapacá region. This arboreal population became practically extinct after being used in the silver and then nitrate refining. In the 1850 s, the wood's scarcity caused its price to become so high that it was replaced by coal brought from Chile or England (Billinghurst, 1893).

${ }^{8}$ This local name was given to small farms that used soil moisture as their only water source. Their production was oriented towards supply ing nitrate mining.
} 
Figure 2: San Pedro nitrate mine, Pampa Negra zone

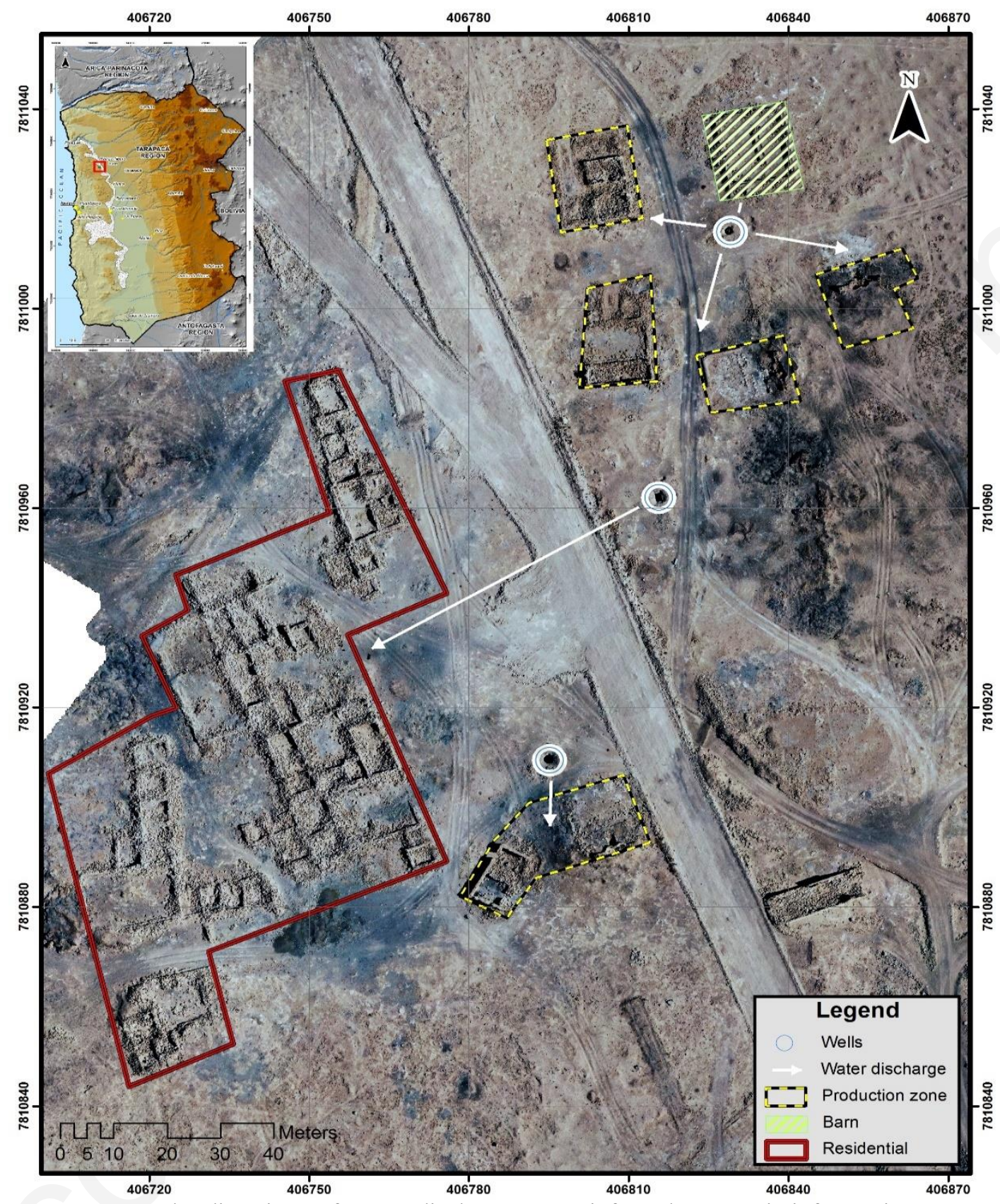

Note: The directions of water discharge were inferred on terrain information.

Source: Elaborated by the authors.

\section{$\underline{\text { Donkey configuration }}$}

The introduction of Tarapacá's nitrate into the European and North American markets in the 1830s stimulated the long-term search for new technical systems. In this context, in 1853, Chilean chemical engineer Pedro Gamboni introduced steam force as the principal element in the nitrate purification process and the entire production system (Puelma, 1855). This technological development necessitated the substantial expansion of mineral production (Bermúdez, 1963) as well as a constant and increased flow of water. 
The introduction of steam in the nitrate industry was associated with different water extraction systems: animal traction (locally named "donkeys," due to the use of this animal), windmills (Figure 3 ), and the first steam engines. ${ }^{9}$ Water was obtained from wells built for exclusively productive purposes. Spatially, the wells were installed in the vicinity of mines (from some meters to a few kilometers). Moreover, where pipes were used, an average of 1.8 kilometers of pipeline length was calculated using Geographical Information Systems.

Figure 3: Water extraction under Donkey configuration (1863)

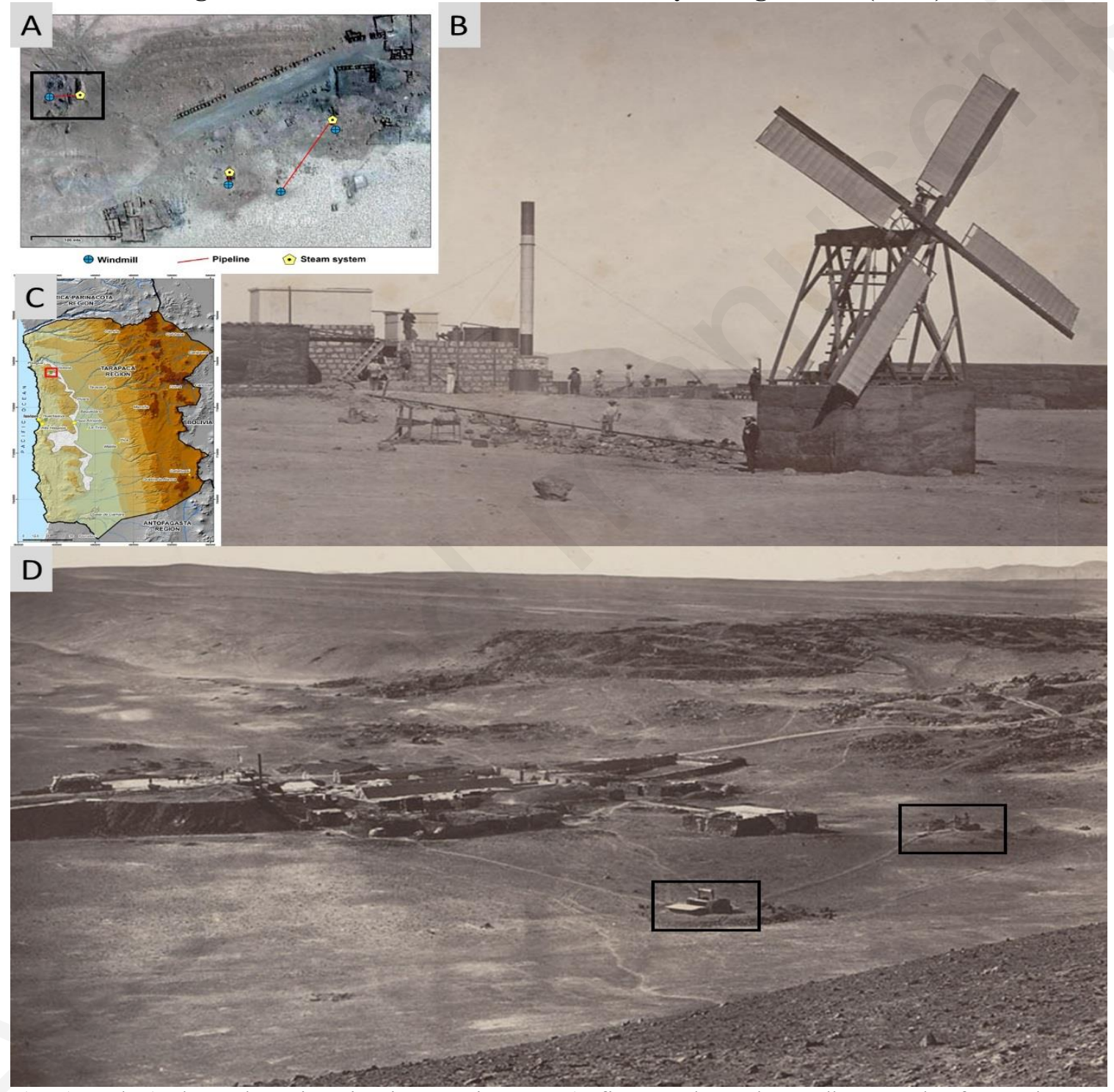

A), B) and C) show the Victoria nitrate mine. In D), figures show the well network of an unknown mine.

Source: W.L. Oliver (1863).

Photograph: Courtesy of University of California Berkeley, Bancroft Library [Oliver Family Photograph Collections, https:/calisphere.org/collections/16189/], accessed February 20, 2019.

\footnotetext{
${ }^{9}$ From 1871 , some mines began to be supplied with fresh water by rail.
} 


\section{Pump configuration}

The shanks refining process was introduced by English industrialist James Thomas Humberstone in 1878. A few months after its installation, the considerable flow of capital and technology from England following the Pacific War ${ }^{10}$ led to the introduction of cutting-edge technologies for the extraction and transportation of water. To supply this essential element to the shank mines, greater volumes (around 38 liters per 46 kilograms of refined nitrate) and a constant supply of the liquid were required. Moreover, this refining technology used a closed circuit of steam, thus necessitating the utilization of "cleaner water" (i.e., containing lower amounts of diluted salts). This compelled the mines to build their wells outside nitrate fields (moving away from production sites), while the use of piping systems was generalized.

These modern "springs" were transformed into isolated spots in the middle of PdT, being alienated from inhabitants, workers, and transportation routes, their sole function being the production of water resources and some agricultural products for the mines they served (Figures 4 and 5). In these places, small houses were built for the pump systems ${ }^{11}$ and habitation of the mechanical workers (in some cases, with his family). These workers oversaw the operation of the machines (Bowman, 1924; Bruggen, 1936) and were the only ones in the industrial nitrate system in "contact" with water.

\footnotetext{
${ }^{10}$ In 1878 , the English capital reached $13 \%$ of the nitrate industry, $34 \%$ by 1884 , and over $70 \%$ by 1890 (Blakemore, 1877 ).

${ }^{11}$ Although different types of water extraction pumps (electric, steam, oil) were identified in historical sources, these technical differences did not imply differences in the everyday practices regarding water at these extraction points.
} 
Figure 4: Alianza pump system in 1899

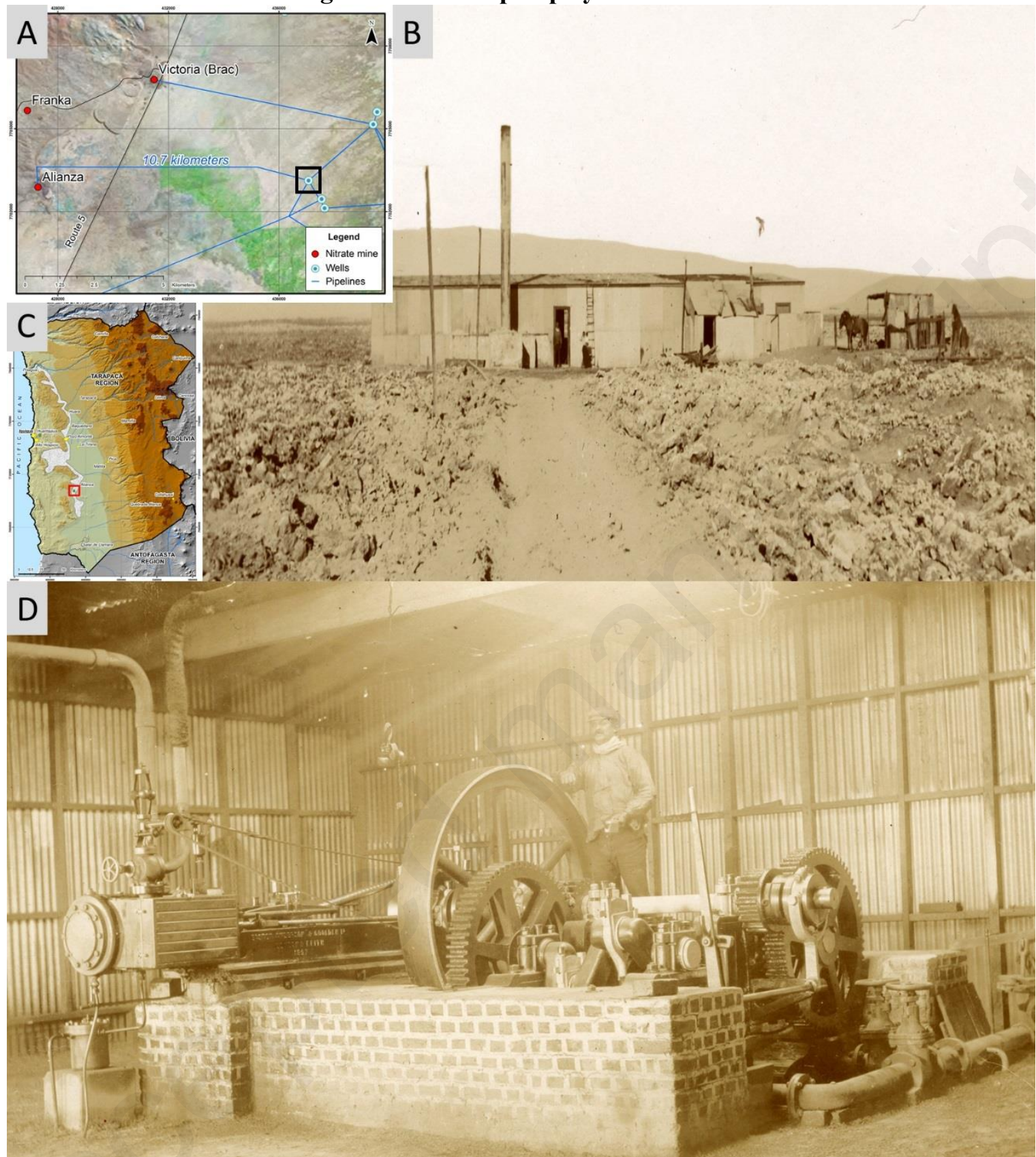

A), C) show the geographical context of the pump system, B) show the exterior of the installations, and D) show the operator standing on the main pump.

Source: J. I. Smail (1899).

(C) Photograph: Traces of Nitrate [Photographic album in the collection of Museo Histórico Nacional, Chile]. 
Figure 5: Vigo pump system

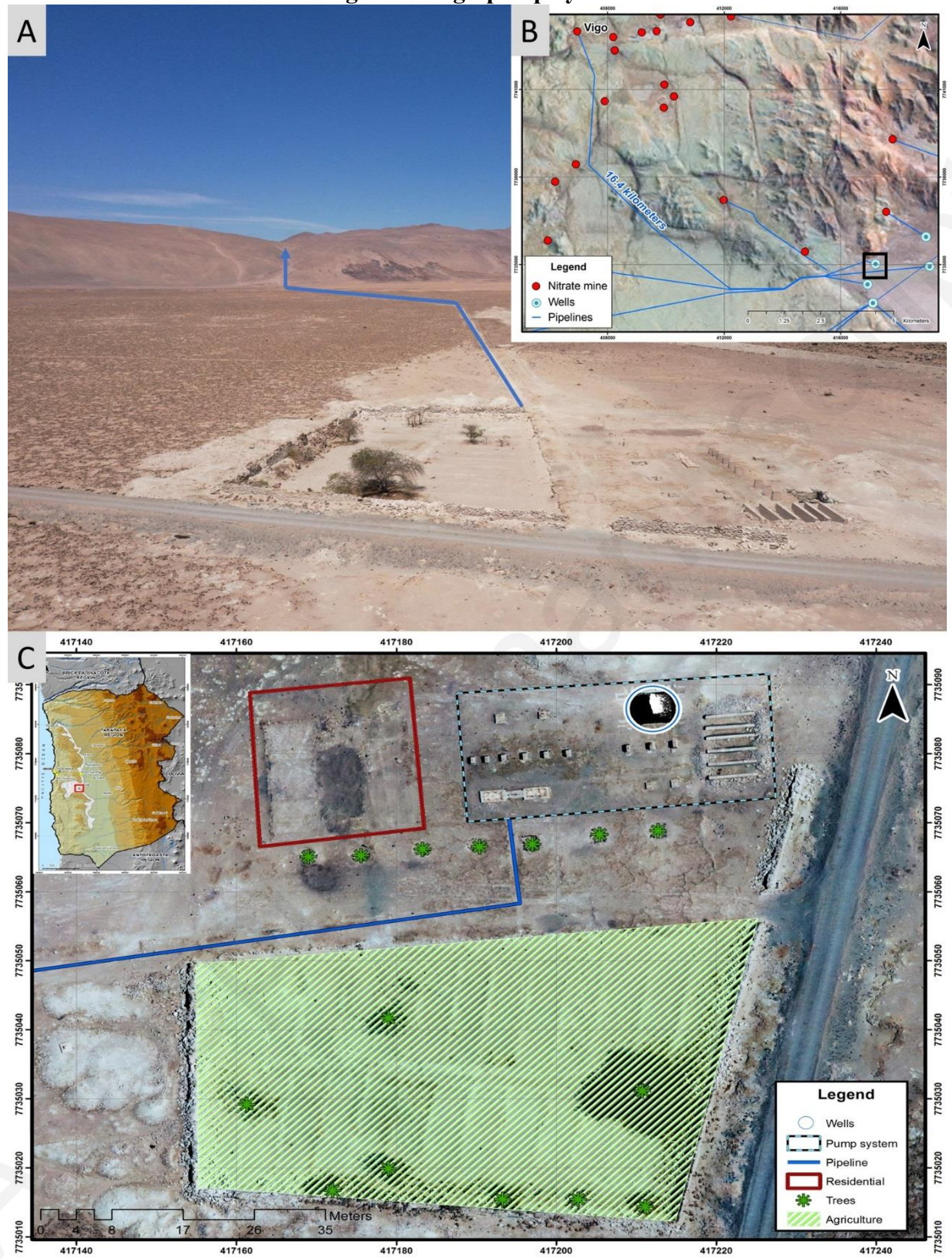

A), B) show the geographical context of the pump system, and C) show a drone-made plan of installations.

Source: Elaborated by the authors. 


\section{HEGEMONIZATION OF MODERN WATERSCAPES IN THE ATACAMA DESERT}

As explained in Section 2, the modernization process could be approached discursively and materially. Therefore, the scientific, technical, and economic discourses on PdT's waters are understood as key discourses for modernizing the Tarapacá waterscapes.

In this way, two elements of these discourses on water are highlighted. On one hand, we analyze the role of science or experts in the production of modern water. Based on water studies carried out during the study period, we propose that these discourses establish a "technological rationality," in which science and industry are the only segments of the society called to produce "systems of truth" of the region (Marcuse, 2004). Similarly, different scholars propose that science represented the means through which the modern society could achieve economic, material, and intellectual progress (e.g., Worster, 1985; Lansing, 1991; Scott, 1998; Mitchel, 2002; Linton, 2010). In the terms of Scott (1998), the scientists were in charge of make "legible" the underground waters of PdT.

Therefore, this discourse of "visibility" of groundwater made possible by science was entwined with the "invisibility" of other approaches to understanding water (Braun, 1997; Méndez et al., 2020); in our case, the approach is the production of premodern waterscapes by indigenous communities. We agree with Strang (2004, p. 246), who proposes that modern water "denies local reality, specific socioenvironmental relationships, alienating it from the environment through which individuals can identify it locally $[. .$.$] water is transformed into a metaphorical abstraction... that has ceased to belong$ to any place or social group."

On the other hand, we propose that the insertion of the idea of "potable water" produced the emergence of "good" and "bad" waters. The scientific criteria that defines potable water are closely related to European hygienist parameters (Fijalkov, 2012). In this way, foreign experts or scientists came to determine whether the waters were good or bad using "objective" principles stemming from centers of politics and economic power at a global and/or national scale. These hydrogeological scientific discourses transformed water into a numerical or chemical formula and stripped of all connection with society.

Therefore, we propose that the scientific and technical discourses on water produced during the nitrate mining boom, acquired a dominant position. These discourses were produced and reproduced by the scientific elites of the nascent states in Lima and/or Santiago and became hegemonic at the end of the $19^{\text {th }}$ century by the introduction of the idea of nature/water as a resource in the Chilean water legislation of 1893 (Méndez et al., 2020).

Materially, over just a few decades of modern production of nitrate, water was sepa rated from society, technologized, and transformed into an economic resource integrated into the global circuit of commodities. Despite that the industrial water extraction and conduction systems "buried" this element, water continued to be at the center of the nitrate production.

Additionally, the different technological characteristics of the nitrate refining systems produced strong changes in the everyday practices around water in PdT, going from complex socioenvironmental systems of water production (spring configuration) to exclusively technical and economic production (donkey and pump configurations).

When these PdT modern waterscapes materially intersected other conceptions of water in the region (indigenous and local communities), they provoked the first modern conflict around water in Tarapacá: the case of the waters of Quisma Valley. After a long dispute between local communities, the state and nitrate industry (1912-1923), the waters of Quisma were expropriated and began to flow 
towards their most efficient use: the production of nitrate (and subsequently towards the urban supply of the city of Iquique) (Castro, 2010). We thus propose that the process of dispossession of the Quisma indigenous community is inseparable from the long-standing transformation of regional waters into a modern resource, which is the result of discourses, knowledge, authority, power relations, rules, and water infrastructure, among others.

Further, the Tarapacá case is similar to studies conducted in the Antofagasta region (Godoy and Méndez, 2018; Méndez et al., 2020), in that both studies propose that the production of the mining territories in the Andes are entwined with the production of uneven modern waterscapes. Similarly we agree with Swyngedouw that modern waterscapes were the results of an "assemblage of interwoven processes that are simultaneously human, nonhuman, material, discursive, mechanical, and organic, but ultimately driven by political forces and economic processes that aspire to turning nature into capital, a process that necessary implies changing social relations to nature" (Swyngedouw, 2015, p. 21).

\section{CONCLUSIONS}

During the production of the modern waterscapes of Tarapacá, three intertwined processes were identified. The first began with the discursive construction of different scientists who, autonomously or by being contracted by the Peruvian and Chilean states, initiated the "enlightenment" of the different zones of Tarapacá, taxonomizing minerals and waters. The scientific discourses on water profusion in Tarapacá escaped the colonial narratives that constructed Tarapacá region as a dry space. Accordingly, these discourses produced water as an element $\left(\mathrm{H}_{2} \mathrm{O}\right)$ completely separate from society: modern water. In this way, it became an economic resource, whose most profitable use was associated with nitrate mining. Additionally, these modern discourses rendered invisible the complex discourses and materialities on water that the local communities of Tarapacá produced over the last 3,000 years BP. Comparable aspects have been identified by Worster (1985) in the American West, Lansing (1991) in Bali, Frederiksen (2013) in Zambia, Hommes and Boelens (2018) in Lima, Peru, and Méndez et al. (2020) in Taltal, Chile.

Entangled with these modern discourses on water, begins the process of socio-political hegemonization of this understanding of water as a resource. Therefore, in the context of "water abundance" in the second half of the $19^{\text {th }}$ century, geology and hydrology (science) became the only ways to find and extract water in sufficient quantities to facilitate the development of mining. Additionally, these scientific discourses were co-produced and implemented by the nascent political elites of Peru and Chile as informal laws and norms.

Through the installation of the "technological rationality" in Tarapacá, the efficiency of production was a recurrent discourse of the mining industry in the region. In this context, the introduction of cutting-edge technologies for the extraction and transportation of water led to the material extirpation of water from the social and economic activities in PdT. The sites of water extraction were transformed into isolated points, dominated by mechanical technologies brought over from Europe or the United States. Furthermore, these technological nitrate production systems materializes the interdependence between the production of nature (water and nitrate), of capital (commodities), and of modern society (waterscapes).

To conclude, we propose that the production of modern water in the Atacama Desert must be understood as a complex, multivariate, and long-standing socioenvironmental process. In this sense, the geohistorical perspective of the genealogical approach in the study of territories exposes new perspectives in the understanding of the long-term discursive and material processes that led to water 
modernization. Additionally, the analysis of the modernization of Tarapacá's waters proposes that the struggles regarding water in northern Chile and the Meridional Andes are related to socio-political processes that began before the arrival of neoliberal policies.

\section{$\underline{\text { REFERENCES }}$}

Álvarez, S., 2014. Etnopercepción Andina: Valles dulces y valles salados en la vertiente occidental de Los Andes. Diálogo Andin. 44, 5-14.

Arroyo, A., Boelens, R. (Eds.), 2013. Aguas Robadas. Despojo Hídrico y Movilización Social. Justicia Hídrica/Abya Yala/Instituto de Estudios Peruanos, Lima.

Barnard, H., Dooley, A., 2017. An ancient irrigation canal in the Pampa Tamarugal (Chile). J. Field Archaeol. 42, 259-268.

Bauer, C., 1995. Against the Current? Privatization, Markets and State in Water Rights in Chile: 19791993. University of California Press, Berkeley.

Bebbington, A., Williams, M., 2008. Water and mining conflicts in Peru. Mt. Res. Dev., 28, 190-195.

Bermúdez, O., 1963. Historia del Salitre, Desde Sus Orígenes Hasta la Guerra del Pacífico. Ediciones Universidad de Chile, Santiago.

Billinghurst, G., 1887. El Abastecimiento de Agua Potable del Puerto de Iquique. Imprenta Es pañola, Iquique.

Billinghurst, G., 1893. La Irrigación de Tarapacá. Imprenta y Librería Ercilla, Santiago.

Blake, J., 1843. Geological and miscellaneous notice of the Province of Tarapacá. Am. J. Sci. Art. $44,1-12$.

Blakemore, H., 1977. Gobierno Chileno y Salitre Inglés 1886-1896: Balmaceda y North. Editorial Andrés Bello, Santiago.

Boelens, R., Cremers, L., Zwarteveen, M. (eds.), 2011. Justicia Hídrica. Acumulación, Conflicto y Acción Social. Justicia Hídrica/Instituto de Estudios Peruanos, Lima.

Bollaert, W., 1851. Observations on the geography of southern Peru, including survey of the Province of Tarapacá, and route to Chile by the coast of the Desert of Atacama. J. RoyalGeogr. Soc. Lon. 21, 99-130.

Bollaert, W., 1860. Antiquarian, Ethnological and Other Researches in New Granada, Equador, Peru and Chile, with Observations on the Pre-Incarial, Incarial and Other Monuments of Peruvian Nations. Trübner \& Co. Paternoster Row, London.

Bowman, I., 1924. Desert Trails of Atacama. Special publication no. 5. New York: American Geographical Society.

Braun, B., 1997. Buries epistemologies: The politics of nature in (post)colonial British Columbia. Ann. Assoc. Am. Geogr. 87, 3-31. 
Braun, B., 2000. Producing vertical territory: Geology and governmentality in late Victorian Canada. Ecumene 7, 7-46.

Bruggen, J., 1921. El agua subterránea en el norte de Chile. Ann. Univ. Chile, 146, 317-340.

Bruggen, J., 1936. El Agua Subterránea en la Pampa del Tamarugal y Morfología General de Tarapacá. Imprenta Universitaria, Santiago.

Budds, J., 2004. Power, nature and neoliberalism: the political ecology of water in Chile. Singap. J. Trop. Geogr. 25, 322-342.

Budds, J., 2009. The 1981 water code: The impacts of private tradable water rights on peasants and indigenous communities in Northern Chile, in: Williams, A. (Ed.), Lost in the Long Transition: Struggles for Social Justice in Neoliberal Chile. Lexington Books, Lanham, pp. 41-62.

Budds, J., Hinojosa, L., 2012. Restructuring and rescaling water governance in mining contexts: The co-production of waterscapes in Peru. Water Altern. 5, 119-137.

Bury, J., Bebbington, A., 2013. New geographies of extractives industries in Latin America, in: Bebbington, A., Burty, J. (Eds.), Subterranean Struggles: New Dynamics of Mining, Oil, and Gas in Latin America. University of Texas, Austin, pp. 27-66.

Cariola, C., Sunkel, O., 1982. La Historia Económica de Chile 1830 y 1930: Dos Ensayos y Una Bibliografía. Ediciones Cultura Hispánica del Instituto de Cooperación Iberoamericana. Madrid.

Carrasco, A., 2015. Jobs and kindness: W.E. Rudolph's role in the shaping of perceptions of mining company-indigenous community relations in the Atacama Desert, Chile. Extr. Ind. Soc. 2, 352-359.

Castro, L., Guerrero, P., Figueroa, C., 2016. La expedición de Antonio Raimondi a la Provincia de Tarapacá y la construcción estatal de un territorio nacional peruano: comentarios y transcripción de su cuaderno de campo (1853-1854). Estud. atacam. 54, 111-152

Castro, L., 2010. Modernización y Conflicto Social. La Expropiación de las Aguas de Regadío a los Campesinos del Valle de Quisma (Oasis de Pica) y el Abastecimiento Fiscal a Iquique, 1880-1937. Editorial Universidad de Valparaíso, Valparaíso.

Castro, M., 2004. Comunidades campesinas: Fronteras móviles en el desierto del norte de Chile, in: Salas, H., Pérez-Taylor, R. (Eds.), Desierto y Fronteras. El Norte de México y Otros Contextos Culturales. Universidad Nacional Autónoma de México, Ciudad de México, pp. 101-122.

Church, M., 1863. Aguas para las Pampas del Tamarugal. An. Cuerpo Ing. Perú, 1, 1874, 61-66.

Darwin, C., 1878. Journal of Researches into the Natural History and Geology of the countries Visited During the Voyage of H.M.S. Beagle Round the World, Under the Command of Capt. Fitz Roy. D. Appleton and Company, New York.

D’Ayzac, L., 1855. Les mines du salpêtre au Pérou. Journal Pour tous, 30 June, 203-206.

De Vivar, J., 1558. La Crónica y la Relación Copioso y Verdadera de los Reinos de Chile. Fondo Histórico y Bibliográfico José Toribio Medina, Santiago. 
Donoso, C., 2008. Prosperidad y decadencia del mineral de Huantajaya: una aproximación. Rev. Diálogo Andin. 32, 59-70.

Ekers, M., Loftus, A., 2008. The power of water: developing dialogue betweenFoucault and Gramsci. Environ. Plan. D: Soc. Space 26, 698-718.

Elden, S., 2010. Land, terrain, territory. Progr. Hum. Geogr. 34, 799-817.

Fernández, M., 1981. Technology and British nitrate enterprises in Chile, 1880-1914. Occasional papers no. 34. Institute of Latin American Studies, University of Glasgow.

Fijalkov, Y. 2012. L'hygienisme au chevet de la ville malade, in Levy, A. (Ed.), Ville, Urbanisme, Santé. Les Trois Révolutions. Editions Pascal, Paris, pp. 113-136.

Forbes, D., 1860. On the geology of Bolivia and southern Peru. Proceedings of the Geological Society, nov. 21, 1860, 7-62.

Foucault, M., 1975. Surveiller et Punir. Naissance de la Prison. Gallimard, Paris.

Frederiksen, T., 2013. Seeing the copperbelt: Science, mining and colonial power in Northem Rhodesia. Geoforum 44, 271-281.

Godoy, M., Méndez, M., 2018. Apenas tenemos aguas para nuestras máquinas: Estado, minería y tecnologías hídricas en el desierto de Atacama, Taltal 1870-1930. Caravelle 111, 25-40.

González, S., 2011. Auge y crisis del nitrato chileno: La importancia de los viajeros, empresarios y científicos, 1830-1919. Rev. Tiempo Hist. 2, 159-178.

González, S., 2014. Las inflexiones de inicio y término del ciclo de expansión del salitre (18721919). Una crítica al nacionalismo metodológico. Rev. Diálogo Andin. 45, 39-49.

Graffam, G., Rivera, M., Carevič, A., 1996. Ancient metallurgy in the Atacama:Evidence for copper smelting during Chile's early Ceramic Period. Lat. Am. Antiq. 7, 101-113.

Harvey D., 1996. Justice, Nature and the Geography of Difference. Blackwell Publishing, Malden.

Hernández, R., 1930. El Salitre. Resumen Histórico Desde su Descubrimiento y Explotación. Asociación de Productores de salitre de Chile, Santiago.

Hommes, L., Boelens, R., 2018. From natural flow to "working river": Hydropower development, modernity and socio-territorial transformations in Lima's Rímac watershed. J. Hist. Geogr. 62, 8595.

Kaika, M., 2006. Dams as symbols of modernization: The urbanization of nature between geographical imagination and materiality. Ann. Assoc. Am. Geogr. 96, 276-301.

Karpouzoglou, N., Vij, S., 2017. Waterscape: A perspective for understanding the contested geography of water. Wires Water 4, p. 1210. 
Lansing, S., 2007. Priests and Programmers: Technologies of Power in the Engineered Landscape of Bali. Princeton University Press, Princeton.

Latour, B., 1991. Nous n'avons jamais été modernes: Essai d'anthropologie symétrique. La découverte, Paris.

Linton, J., 2010. What is Water? The History of a Modern Abstraction. University of British Columbia Press, Vancouver.

Marcuse, H., 2004. Some social implications of modern technology, in: Marcuse, H. (Ed.), Technology, War and Fascism (Vol. 1). Routledge, New York, pp. 59-86.

Martínez, G., 1987. Para una etnografía del riego en Chiapa. Chungará, Rev. Antropol. Chil. 18, 163179.

Méndez, M., Romero, H., 2018. Construcción de los territorios altoandinos de Tarapacá, norte de Chile. Reflexión conceptual desde una perspectiva histórico-geográfica. Rev. Chil. Antropol. 37, 183-196.

Méndez, M., Romero, H., 2020. Territorios hidrosociales en las geografías altoandinas del norte de Chile: modernización y conflictos en la región de Tarapacá. Idées d'Am. 15/2020, 1-28.

Méndez, M., Prieto, M., Godoy, M., 2020. Production of subterranean resources in the Atacama Desert: $19^{\text {th }}$ and early $20^{\text {th }}$ century mining/water extraction in the Taltal district, northern Chile. Polit. Geogr. 81, 1-12.

Mitchel, T., 2002. Rule of Experts: Egypt, Techno-Politics, Modernity. University of California Press, Berkeley.

Molina, F., 2012. Competing rationalities in water conflict: mining and the indigenous community in Chiu, El Loa Province, northern Chile. Singap. J. Trop. Geogr. 33, 93-107.

Nyre, E., 2020. Pounds Sterling to Dollars: Historical Conversion of Currency. Accessed Monday, April 20, 2020, https:/www.uwyo.edu/numimage/currency.htm

Núñez, L., 1985. Recuérdalo, aquí estaba el lagar: La expropiación de las aguas del valle de Quisma. Chungará, Rev. Antropol. Chil. 14, 157-167.

Núñez, L., 1987. Tráfico de metales en el área centro-sur Andina: Factos y expectativas. Cuad. Inst. Nac. Antropol. 12, 73-105.

O’Brien, A., 1765. Plano que Manifiesta el Valle o Pampa de Yluga en el Tenientazgo de Tara pacá. Registros de la Provincia de San Marcos de Arica.

Peluso, N., Vandergeest, P., 2001. Genealogies of the political forest and customary rights in Indonesia, Malaysia, and Thailand. J. Asian Stud. 60, 761-812.

Perreault, T., 2006. From the guerra del agua to the guerra del gas: Resource governance, neoliberalism, and popular protest in Bolivia. Antipode 38, 150-172. 
Perreault, T. (ed.), 2014. Minería, Agua y Justicia Social en Los Andes. Experiencias Comparativas de Perú y Bolivia. Justicia Hídrica/Centro Bartolomé de las Casas, Lima.

Prieto, M., 2015. Privatizing water in the Chilean Andes: The case of Las Vegas de Chiu-Chiu. MT. Res. Dev. 35, 220-229.

Prieto, M., 2019. The dispossession of the San Pedrode Inacaliri river: political ecology, extractivism and archaeology. Extr. Ind. Soc., 6, 562-572.

Puelma, F., 1855. Apuntes jeolójicos y jeográficos sobre la Provincia de Tarapacá en Perú, acompañados de una lijera noticia sobre la esplotación del nitrato de soda. An. Univ. Chile, Serie 1, 665-673.

Raimondi, A., 1882. Aguas Minerales del Perú. Estudios Geológicos del Perú, Tercera Parte, Lima.

Raimondi, A., 1884. Aguas Potables del Perú. E. Macias y Co Editores, Lima.

Romero, H. Méndez M., Smith, P., 2012. Mining development and environmental injustice in the Atacama Desert of Northern Chile. Environ. Justice, 5, 70-76.

Ruiz, J., 2009. Análisis sociológico del discurso: métodos y lógicas. Forum: Qual. Soc. Res. 10, 26.

Salazar, D., Jackson, D., Guendon, J., Salinas, H., Morata, D., Figueroa, V., Manríquez, G., Castro, V., 2011. Early evidence (ca. 12,000 BP) for iron oxide mining on the Pacific coast of South America. Curr. Anthropol. 52, 463-475.

Santoro, C., Capriles, J., Gayó, G., De Porras, M., Maldonado, A., Standen, V., Latorre, P., Castro, V., Angelo, D., Mcrostie, V., Uribe, M., Valenzuela, D., Ugalde, P., Marquet, P., 2017. Continuities and discontinuities in the socio-environmental systems of the Atacama Desert during the last 13,000 years. J. Anthropol. Archaeol. 46, 28-39.

Scott, J., 1998. Seeing Like a State: How Certain Schemes to Improve the human Condition Have Failed. Yale University Press, New Haven.

Semper, E., Michels, D., 1908. La Industria del Salitre en Chile. Imprenta, litografía y encuadernación Barcelona, Santiago.

Smith, N., 2008. Uneven Development: Nature, Capital and the Production of Space, third ed. The University of Georgia Press, Athens.

Strang, V., 2004. The Meaning of Water. Berg, Oxford \& New York.

Svampa, M., 2019. Las Fronteras del Neoextractivismo en América Latina. Conflictos Socioambientales, Giro Ecoterritorial y Nuevas Dependencias. Bielefeld University Press, Bielefeld.

Swyngedouw, E., 1996. The city as a hybrid: On nature, society and cyborg urbanization. Cult. Nat. Social. 7, 65-80.

Swyngedouw, E., 1999. Modernity and hybridity: Nature, regeneracionismo and the production of the Spanish waterscape. Ann. Am. Assoc. Geogr. 89, 443-465. 
Swyngedouw, E., 2015. Liquid power: Contested hydro-modernities in twentieth-century Spain. Cambridge: The Massachusetts Institute of Technology Press.

Thompson, I., 2005. La Nitrate Railways Co. LTD.: La pérdida de sus derechos exclusivos en el mercado del transporte de salitre y su respuesta a ella. Rev. Hist. 38, 85-112.

United States Geological Service (USGS), 2019. Mineral Commodity Summaries 2019. USGS, Reston.

Valencia, A., 2004. Guasquiña, un pueblo precordillerano. Archiv. Filol. Aragon. 2, 1709-1729.

Van Kessel, J., 1985. La lucha por el agua de Tarapacá: la visión andina. Chungará: Rev. Antropol. Chil. 14, 141-155.

Van Kessel, J., 2003. Holocausto al Progreso: Los Aymara de Tarapacá. Instituto para el Estudio de la Cultura y Tecnología Andina (IECTA), Iquique.

Worster, D., 1985. Rivers of Empire: Water, Aridity, and the Growth of the American West. Oxford University Press, New York.

Yáñez, N., Molina, R., 2008. La Gran Minería y los Derechos Indígenas en el Norte de Chile. LOM Ediciones, Santiago.

Yáñez, N., Molina, R., 2011. Las Aguas Indígenas en Chile. LOM Ediciones, Santiago. 